\title{
Verbalization of the Writer
} in Academic Prose

\author{
Olga A. Krapivkina* \\ Irkutsk National Research Technical University \\ 83 Lermontov Str., Irkutsk, 664074, Russia
}

Received 07.10.2014, received in revised form 19.02.2015, accepted 03.03.2015

\begin{abstract}
The paper presents an empirical analysis of the tools writers use to verbalize their stances in academic discourse based on a corpus of 40 research articles in the fields of Humanities. The paper distinguishes between three stances of writers in academic discourse which are verbalized with a number of linguistic tools: the researcher, the opinion holder, and the representative. The paper also aims to examine the cultural conditions as well as the role of writer's research experience in markers' preferences. The paper describes a study in which frequency and usage of linguistic tools marking writer's stances were compared between papers written in English and in Russian. It was found that Russian authors preferred first-person plural pronouns, the third person and agentless passives while English language writers used both first-person singular and plural, agentless constructions, third person with human reference, and personified point of view constructions.
\end{abstract}

Keywords: writer, academic discourse, linguistic tool, pronoun, discourse stance.

DOI: 10.17516/1997-1370-2015-8-8-1625-1634.

Research area: law.

\section{Introduction}

Academic discourse is not only reporting new ideas and research results. It is representing the writer's stances, expressing the writer's opinion, constructing solidarity with both readers and the academic community, and organizing the discourse. These functions are performed by using different markers of the writer in discourse. Among these markers, one could mention first person pronouns, third person with human reference (author, researcher, etc.), agentless and personified point of view constructions.

The research is of great value for those students, especially for Russian ones, who are going to write academic works and should be able to position themselves appropriately in relation to their work following the conventions of the academic community.

It should be noted that standards for academic writing disagree about the usage of first person singular pronouns in academic prose. Some argue that personal pronouns distract from what should be objective and scientifically valid, or even that personal statements do not sound "scientific". Personal pronouns could play a distracting role in papers aimed at analyzing data where the focus should be on the phenomena under study rather than on the writer's personality. They are

(C) Siberian Federal University. All rights reserved

* Corresponding author E-mail address: olgak78@mail.ru 
often believed to be contrary to the requirements of formality in academic discourse. The use of impersonal and passive constructions is proposed by textbooks as a means allowing writers to speak to readers in an unbiased way.

Others argue that omitting first-person pronouns results in awkward, passive sentences rather than direct "We did X" ones. Some researchers [2] believe that academic writing should use personal pronouns because they emphasize that a human was involved in the work. Voice realized through the use of personal pronouns in academic writing is the sound of the individual on the page. However when reporting universal scientific facts or observations, Bernard adds, personal pronouns should be omitted as far as any reasonable observer would have reported similar results and thus there is no need to emphasize the role of the writers (ibid.).

According to Hyland [10], personal pronouns in academic discourse are a valuable strategy which allows writers to construct academic credibility. Cherry [4] argues that personal pronouns help the writer state opinions and organize discourse. Without these pronouns it is sometimes rather difficult to say the same thing more effectively, more forcefully [12]. Ivanič [13] even suggests that if the writer "depersonalizes ideas", this could cause trouble for both readers and the writer.

Kuo [16] believes that knowledge of the strategic use of linguistic markers of the writer in academic discourse allows emphasizing his/her personal contributions to the field and stressing solidarity with potential readers.
The present paper aims at categorizing the linguistic tools used to verbalize the writer's stances in academic discourse. The stances we have distinguished in academic papers under consideration are as follows:

1) the researcher,

2) the opinion holder,

3) the representative.

Our taxonomy of writer's stances in academic prose is based on the Tang and Jones' [20], Vladimirou' [22] and Munoz' [18] classifications of writer's roles in academic writing. It should be mentioned that there have been proposed a number of taxonomies for the classification of writer's pronouns $[8 ; 9 ; 10 ; 11 ; 13 ; 16 ; 20 ; 21]$.

Based on the analysis of 40 foreign and Russian academic papers we have suggested the existence of a continuum ranging from the omission of first-person pronouns to the use of "I" to verbalize various writer's roles or stances in academic discourse.

Figure 1 shows degrees of writer's involvement in the work. The most powerful authorial involvement stands at the left end of the scale.

The researcher undertakes the study, involving different degrees of agency. S/he shows the reader through the paper, draws the reader's attention to the issues of his/her essay, organizes, structures, and outlines the material in the essay, describes the various steps of the research process.

The opinion holder shares an opinion, view or attitude, expresses agreement or disagreement with regard to known information or established facts.

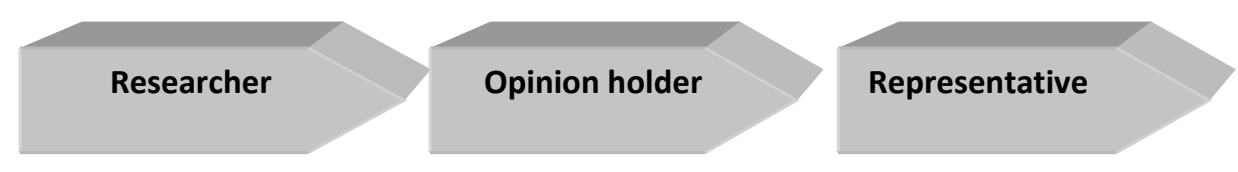

Fig. 1. Writer's stances in academic discourse 
The representative is the role of the writer who acts as a proxy for a larger group of people.

\section{Materials and Methods}

The method applied for this study is based on qualitative and quantitative analysis of linguistic tools used to verbalize the writer in academic discourse. The qualitative approach aims at investigating the pragmatic functions of linguistic markers of the writer in academic discourse to understand the writer's choice. The quantitative method is applied to find out the frequency of use of linguistic markers in academic papers in Russian and English.

The corpus used in this study consists of 40 journal papers in the field of Humanities in English and in Russian. The length of each text under study is about 8,000-9,000 words.

The discourse functions performed by linguistic tools (personal pronouns, descriptions, impersonal and passive constructions) have been analyzed based on the above suggested taxonomy of writer's stances.

\section{Results}

The frequency with which different linguistic markers are used in academic discourse in English and Russian is summarized in Table 1.

As can be inferred from Table 1, in the English-language (EL) papers, scholars tend to make their personality more visible. The expression of a strong self can be explained by the wish to be seen in a text presenting the extent and importance of their contribution, or it demonstrates that they take full responsibility for their claims. All the above mentioned stances have been found in EL papers.

Nevertheless, it should be noted, not all the writers in their EL papers used I-pronoun. Some of them avoided the "egocentric" pronoun in their writing. First-person reference scored a high frequency in the Introduction section where authors signal explicit commitment to their work playing the role of the researcher.

'We'-pronoun is used in both EL and RL (Russian-language) prose, but the EL papers feature rather more instances of the first-person plural as well as the first-person singular.

The results of the analysis show that in the RL papers, the use of personal pronouns does not seem to be a predominant feature of writing, while EL papers feature a number of first-person singular and plural pronouns.

The total proportion of EL papers which show instances of first-person plural pronouns is $100 \%$. The total proportion of RL papers which show instances of first-person plural pronouns is $80 \%$ while the total proportion of RL papers which show the instances of first-person singular is $0 \%$. At the same time, the proportion of EL languages with first person instances is $30 \%$.

Agentless constructions are widespread both in the EL and RL papers. Third person with human reference has been found only in the RL papers while personified point of view constructions are typical only of the EL prose.

Table 1. Frequency of linguistic markers of the writer in EL and RL papers

\begin{tabular}{|c|c|c|c|c|c|c|c|c|c|}
\hline \multicolumn{2}{|c|}{$\begin{array}{l}\text { First person } \\
\text { singular }\end{array}$} & \multicolumn{2}{|c|}{ First person plural } & \multicolumn{2}{|c|}{$\begin{array}{c}\text { Third person with } \\
\text { human reference } \\
\text { (the researcher, the } \\
\text { author) }\end{array}$} & \multicolumn{2}{|c|}{$\begin{array}{c}\text { Agentless } \\
\text { constructions }\end{array}$} & \multicolumn{2}{|c|}{$\begin{array}{l}\text { Personified point of } \\
\text { view constructions }\end{array}$} \\
\hline EL & $\mathrm{RL}$ & EL & $\mathrm{RL}$ & EL & $\mathrm{RL}$ & EL & $\mathrm{RL}$ & EL & RL \\
\hline 56 & 0 & 157 & 143 & 0 & 34 & 345 & 260 & 334 & 0 \\
\hline
\end{tabular}


I will first analyze the RL papers and their instances of linguistic markers of the writer.

I have found the instances of all linguistic markers of the writer listed in Table 1. Let us consider the examples of different uses of firstperson pronouns.

1) Uses of first-person plural to mark the stance of the researcher:

Мы опять видим, что ...

[We see again that ...].

Мы видим фактическое повторение Уорфом идеи Сепира ...

[We see that Whorf adopt Sepir's idea ....].

These are the instances of an inclusive 'мы' (we) in the role of the researcher to draw the reader's attention to certain points of the paper.

В рамках настоящей статьи мы ограничимся рассмотрением некоторых деталей...

[For the purpose of this article, we confine ourselves to studying some details...].

In this example, the writer uses мы-pronoun instead of the first-person singular to refer exclusively to herself.

2) Uses of first-person plural to mark the stance of the opinion holder:

Мы полагаем, что подобный анализ ситуации является едва ли не единственно возможным.

[We believe that such case study is the only one possible].

The example shows that the writer uses 'мы' (we) to refer to herself. It is an exclusive 'we' functioning as the opinion holder employed instead of ' $\mathrm{I}$ '.

В первую очередь мы говорим о полноценных сформировавшихся обществах...

[First of all, we speak about healthy, developed societies].
Под виртуальными фановскими практиками мы понимаем любую деятельность, осуществляемую в он-лайн пространстве.

[We define fan practices as any on-line activities].

As seen from the examples above, the writer uses 'мы' (we) to mark the stance of the opinion holder - the writer shares her views with readers.

3) Uses of first-person plural to mark the stance of the representative:

Однако главное, что выиграли все мы, получив возможность читать такие разные и такие замечательные переводы «Гамлета».

[However, it is important that all of us got a chance to read so different and so beautiful translations of "Hamlet"].

In the above example, 'we' is a generic firstperson pronoun that the writer uses as a proxy for a larger group of people.

Если мы считаем род несущественным, то русские могут удивляться тому, почему мы полагаем необходимым каждый раз указывать ...

[If we consider the gender irrelevant, the Russians might be surprised why we think it is necessary to mark it each time ...].

In the example, 'we' performs the function of the representative - the writer speaks on behalf of all people.

Summarizing the uses of first-person pronouns in the RL papers, we can conclude that they show no instances of ' $r$ '(I)-pronoun, while the instances of 'мы' (we) are rather numerous.

We can state several explanations of the tendency to avoid using first-person singular pronouns:

1) the manifestation of politeness, cooperation, academic courtesy [5]; 
2) the manifestation of academic "modesty" [6; 7];

3) the aim to present one's opinion as a collective opinion of a certain group of people, academic school, thus making it more meaningful [3];

4) the aim to avoid subjectivity, to emphasize the opinion rather than its author [14];

5) the manifestation that the paper is based on the works of other authors in the field [ibid.];

6) the ideological dictate disowning writer's personality [17].

$W e$ in academic discourse "hides" $I$, neutralizes it, Rudenko [19] says. Many researchers believe that we for $I$ in academic discourse is more typical for the Russian mindset and culture. According to Karasik [15], the meaning of the authorial we involves the status component. Arnold [1] argues that the first-person singular is appropriate in works of recognized writers while novices have to avoid egocentric structures.

The more convincing explanation of using we for $I$ is rooted in differences between two ideologies - collectivism vs. individualism. The uses of we argue for the community priority while the uses of $I$ - for the individual one.

We can suggest that the pronominal choice depends heavily on the conventions of the academic community which, in turn, are culturally and ideologically conditioned. The writer's level of experience in research field appears to be one more factor determining the pronominal choice.

Let us now consider the uses of third person with human reference in the RL papers. It is noteworthy that this tool was used only for some of the stances considered.

1) Uses of third person with human reference to mark the stance of the researcher:

Ранее автором было предложено воспользоваться междисциплинарным подходом для исследования прагматики корпуса текстов, т.е. вопросов двунаправленного взаимодействия между корпусом и его конечным пользователем.

[Previously the author suggested using an interdisciplinary approach to study the pragmatics of the text corpus ...].

The writer draws the reader's attention to his previous work linked to the present issues.

Для проверки соответствия фактического положения дел предложенным теоретическим выкладкам, автором был предпринят предварительный эксперимент с использованием информантов.

[To provide conformity between theory and facts, the author made an experiment with the assistance of informants].

The writer describes the steps of the research process.

2) Uses of third person with human reference to mark the stance of the opinion holder:

Автор настоящей статьи придерживается мнения, что этот срок не может быть более одного года ...

[The author of the present paper believes that the term cannot exceed one year ....

The writer shares an opinion with readers.

Thus, it has been found only two stances verbalized with the third person - the researcher and the opinion holder. As shown in Table 1, it has been found 34 instances of the third person with human reference in 20 RL papers.

Let us now consider the uses of agentless and impersonal constructions in the RL papers. These constructions were used to verbalize only two of four stances of the writer in the Russian language academic discourse.

1) Uses of agentless constructions to mark the stance of the researcher:

Следует в этой связи отметить, что смысловые различия между furchtlos и 
unerschrocken обусловлены, прежде всего, значением отрицательных аффиксов.

[It should be noted that semantic differences between furchtlos and unerschrocken are conditioned by the meaning of negative affixes].

Наблюдается постепенный переход значений одного синонима в смысловой объем других синонимов, что приводит к едва уловимым и нечетко фиксируемым границам между ними.

[The gradual transition of the meaning of one synonym into the meaning of other synonyms is observed. It causes just noticeable and fuzzy differences between them].

The writer draws the reader's attention to the issues under consideration.

2) Uses of agentless and impersonal constructions to mark the stance of the opinion holder:

Поэтому логично предположить, что прилагательное kühn в составе ряда синонимов с доминантой tapfer используется при описании интеллектуальной смелости, присущей человеку храброму.

[For this reason it is under that logic that the adjective kühn in the synonymic row with the dominant tapfer is used to describe the mental courage typical of a brave person].

The writer analyzes the process of synonymic transitions and interprets it.

It should be noted that agentless constructions in the RL papers were the most numerous. They were 460 instances in 20 papers, three times more than the uses of first person point of view constructions and 13,5 times more than the uses of third person. There have been found no instances of first person singular and personified point of view constructions in the RL papers.

Let us proceed to the English language papers and their instances of the linguistic tools used to verbalize the writer in academic discourse.
First, we consider the examples of different uses of first-person singular and plural pronouns to verbalize the writer's stances.

1) Uses of first-person singular to mark the stance of the researcher:

In this paper, I will focus quantitively and qualitatively on a particular form of interpersonal metadiscourse: person markers.

Moving on from the level of semantic reference to the level of pragmatic functions, in this section I will deal with the concept of multifunctionality in personal reference.

The writer is telling the reader what he is going to do. 'I' is used to mark the stance of the researcher who describes various steps of the study. 'I' also appears to indicate that the research process is a decision made by the writer who assumes responsibility for the choices made when conducting the study.

2) Uses of first-person singular to mark the stance of the opinion holder:

I am convinced that the processes of translation and simultaneous interpretation differ fundamentally.

I treat deception as a phenomenon belonging to the class of phenomena defined by the general notion of insincerity....

The writers use 'I' to mark the stance of the opinion holder who expresses his/her personal views.

It is noteworthy that we have found only two stances of the writer marked with first person singular. Let us proceed to the uses of first person plural in the EL papers.

1) Uses of first-person plural to mark the stance of the researcher:

We shall now say it all, but short.

Further on, we would like to focus our attention on one more technology.

'We' is used instead of ' $\mathrm{I}$ ' to perform the role of the researcher. It expresses the writer's 
intention to draw readers' attention to a certain point.

2) Uses of first-person plural to mark the stance of the opinion holder:

More broadly, we suggest that a fully developed theory of backchannel communication includes not only their function as responses to speaker talk, but also their role in pushing unfolding speakers' talk along particular trajectories. (Journal of Pragmatics)

We consider political cartoons as one of the linguistic technologies as well.

The writer uses 'we' to express her suggestion on the theory of backchannel communication in the first utterance, and on political cartoons in the second one.

3) Uses of first-person plural to mark the stance of the representative:

To the extent that we believe the myth that judges "discover" the law, dissents simply represent rejected dead ends along that path of discovery.

The writer speaks for all people who live in a democratic society and believe that judges "discover" the law.

Let us now provide examples of agentless constructions in EL papers to mark different writer's stances.

1) Uses of agentless constructions to mark the stance of the opinion holder:

Thus, Agrifoglio's project can be considered a source of useful knowledge of, among other insights, the threats which may be lurking in a written source text and which the interpreter should be wary of.

The writer puts forth his reflections using the cognitive verb consider in order to express his viewpoint.

2) Uses of agentless constructions to mark the stance of the researcher:

To be more specific, a convenience sampling procedure, which includes picking the required sample from available cases, was used to select the six texts for this study.

The writer describes the steps of the research process using agentless constructions which convey the impression of objectivity.

It is evident from Table 1 that agentless constructions of different types have the highest incidence at 345 occurrences in the EL papers. They are mostly used in recounting the procedures involved in research.

One more linguistic tool used by the EL writers is personified point of view constructions. It should be noted that these constructions are rather widespread in EL papers. In the papers under consideration their number is much the same as the quantity of agentless constructions. In the RL papers, as we have already seen, we have found no instances of personified point of constructions. Let us provide the examples of these constructions which are used to mark the stance of the researcher and only:

The analysis demonstrates that storytellers respond in distinct patterns to the two categories of backchannels.

This paper deals with the multimodal and spatial arrangements of the participants within pre-beginning and opening sequences, i.e. sequences taking place before the actual opening of a social interaction and achieving the conditions for an imminent opening.

This paper aims at laying a groundwork for teaching sight translation, based on concepts and strategies of skill training.

The personified points of view indicate avoidance of a 'potentially problematic role of writer - as - thinker' [11].

The preference for personified points of view constructions as well as for the agentless ones suggests that academic prose requires a high level of objectivity which first personal pronouns are not able to achieve. Such impersonal forms allow an author to 
strategically retreat to the background in order to foreground the findings.

\section{Conclusion}

The current study presented an empirical analysis of the tools English and Russian language writers use to verbalize their stances in academic writing based on a corpus of 40 research articles in the fields of Humanities.

The paper distinguished between three stances of writers in academic discourse which are verbalized with certain linguistic tools: the researcher, the opinion holder, and the representative.

The paper also examined the cultural conditions as well as the role of writer's research experience in pronoun preferences.

The paper described a study in which frequency and usage of linguistic tools marking writer's stances were compared between papers written in English and in Russian. It was found that Russian authors preferred first person plural pronouns, the third person and agentless passives while English language writers used both first person singular and plural, agentless constructions, third person with human reference, and personified point of view constructions.

The paper may be useful in teaching academic discourse as they have to be aware of different pragmatic functions of linguistic tools used to verbalize writer's stances in academic writing. Differences in the use of these tools across English and Russian might be also helpful to Russian students and researchers who wish to publish their papers in international journals as they need to know the rhetorical conventions which are favored in EL academic writing.

\section{References}

1. Arnold, I. Fundamentals of Academic Researches in Linguistics [Osnovy Nauchnykh Issledovaniy v Lingvistike]. Moscow, 1991.

2. Bernard, J.A. Tips for Academic Writing and Other Formal Writing, Available at http:// homepages.inf.ed.ac.uk/jbednar/writingtips.html (accessed 12.01.2014)

3. Boldyreva A.A., Peculiarities of Expressing Author's I in Academic Discourse [Osobennosti vyrazheniya avtorskogo «ya» v nauchnom diskurse], Available at http://tpll999.narod.ru/ (accessed 13.04.2014).

4. Cherry, R.D. Ethos versus Persona: Self-representation in written discourse. Written Communication, 15 (1998), 384-410.

5. Gergokaeva, D.D. Egocentrism of Linguistic Discourse [Egocentrism lingvisticheskogo diskursa]. Moscow., 2008.

6. Glushko, M.M. Structure of the academic text in terms of systemized nature of its pragmatic, semantic and syntactic characteristics. Linguistic researches of Academic Discourse [Organizatsiya nauchnogo teksta $\mathrm{v}$ svete sistemnosti ego pragmaticheskikh, semanticheskikh i sintaksicheskikh kharakteristik. Lingvisticheskie issledovaniya nauchnoi rechi]. Moscow, 1979.

7. Gnezdechko, O.N. Authorization of the Academic Discourse [Avtorizatsiya nauchnogo diskursa: kommunikativno-pragmaticheskii aspect]. Kiev, 2005.

8. Harwood, N. We Do Not Seem to Have a Theory ...The Theory I Present Here Attempts to Fill This Gap: Inclusive and Exclusive Pronouns in Academic Writing. Applied Linguistics, 26/3 (2005), 343-375. 
9. Harwood, N. (In)appropriate Personal Pronoun Use in Political Science: A Qualitative Study and a Proposed Heuristic for Future Research. Written Communication, 23 (4) (2006), 424-460.

10. Hyland, K. Humble servants of the discipline? Self-mention in research articles. English for Specific Purposes, 20 (2001), 207-226.

11. Hyland, K. Authority and invisibility: Authorial identity in academic writing. Journal of Pragmatics, 34 (2002), 109-112.

12. Elbow, P. Writing with power. New York, 1981.

13. Ivanič, R. Writing and identity: The discoursal construction of identity in academic writing. Amsterdam,1998.

14. Ivanov, V.V. Odd or Even. Asymmetry of the Brain and Sign Systems [Chet i nechet. Assimetriya mozga i znakovykh system]. Moscow, 1978.

15. Karasik, V. Language of the Social Status [Yazyk Sotsialnogo Statusa]. Moscow, 1992.

16. Kuo, C-H. The use of personal pronouns: Role relationships in scientific journal articles. English for Specific Purposes, 18(2) (1999), 121-38.

17. Miroshnichenko, A. Interpretation of Discourse: Basics of Linguistic and Ideological Analysis [Tolkovanie Diskursa: Osnovy Lingvisticheskogo i Ideologicheskogo Analiza]. Rostov-na-Donu, 1995.

18. Munoz, M.C. The "I" in Interaction: Authorial Presence in Academic Writing. Revista de Lingüística y Lenguas Aplicadas. Journal of Pragmatics, 8 (2013), 49-58.

19. Rudenko, I. Discourse of Gorbachev's Era [Diskurs gorbachevskoy epokhi]. Komsomolskaya Pravda, 23 (1998).

20. Tang, R. The 'I' identity: Exploring Writer Identity in Student Academic Writing Through the First Person Pronoun. English for Specific Purposes, 18 (1999), 23-39.

21. Vassileva, I. Who Am I / Who are We in Academic Writing? A Contrastive Analysis of Authorial Presence in English, German, French, Russian and Bulgarian. International Journal of Applied Linguistics, 8(2) (1998), 163-90.

22. Vladimirou, D. Personal Reference in Linguistic Journal Articles. Papers from the Lancaster University Postgraduate Conference in Linguistics and Language Teaching, 1 (2006), 139-157. 


\section{Вербализация субъекта в научном дискурсе}

\section{О.А. Крапивкина}

Иркутский государственный технический университет Россия, 664074, Иркутск, Лермонтова, 83

В статье анализируются языковые единицы, используемые для вербализации различных ипостасей автора в научном дискурсе на материале 40 научных статей гуманитарного направления. Выделяются три ипостаси субъекта научного дискурса: исследователь, выразитель мнения, представитель. Автор утверждает, что на выбор средств позиционирования субъекта оказывают влияние культурные факты и опыт научноисследовательской деятельности автора. Проводится статистический и компаративный анализ лингвистических средств, участвующих в вербализаџии ипостасей субъекта в англоязычных и русскоязычных научных статьях. В ходе исследования автор пришел к выводу, что в русскоязычных статьях чаще используются местоимения первого лица множественного числа, третье лицо и бессубъектные конструкиии, в то время как в англоязычных статьях авторы не боятся употреблять местоимения первого лица единственного числа.

Ключевые слова: автор, научный дискурс, языковая единица, местоимение, дискурсивная роль.

Научная спещиальность: 12.00.00 - юридические науки. 